\title{
The influence of acute and chronic hypercalcemia on the parathyroid hormone response to hypocalcemia in rabbits
}

\author{
S Bas, E Aguilera-Tejero, J C Estepa, B Garfia, I López and M Rodríguez ${ }^{1}$ \\ Departamento de Medicina y Cirugía Animal, Universidad de Córdoba, Campus de Rabanales, Ctra Madrid-Cádiz km 396, 14014 Córdoba, Spain \\ and ${ }^{1}$ Departamento de Nefrología y Unidad de Investigación, Hospital Universitario Reina Sofía, Avda Menéndez Pidal s/n, 14004 Córdoba, Spain \\ (Correspondence should be addressed to E Aguilera-Tejero; Email: pv1agtee@lucano.uco.es)
}

\begin{abstract}
Objective: To investigate the influence of acute and chronic hypercalcemia on the parathyroid hormone (PTH) response to hypocalcemia.

Design: The PTH response to hypocalcemia has been evaluated in three groups of rabbits: Group I, normal rabbits, Group II, normal rabbits subjected to an acute hypercalcemic clamp (induced by $\mathrm{CaCl}_{2}$ infusion) and Group III, rabbits with chronic hypercalcemia (due to surgical reduction of renal mass).

Results: In Group I (baseline $\mathrm{Ca}^{2+}=1.69 \pm 0.02 \mathrm{mM}$ ), hypocalcemia resulted in stimulation of PTH secretion which reached a maximum (PTHmax) of $91.7 \pm 6.4 \mathrm{pg} / \mathrm{ml}$. In rabbits from Group II, which also had normal baseline $\mathrm{Ca}^{2+}(1.70 \pm 0.02 \mathrm{mM})$, plasma $\mathrm{Ca}^{2+}$ was maintained at an elevated level for $2 \mathrm{~h}$, at around $2.05 \mathrm{mM}$. The PTH response to hypocalcemia in Group II was attenuated and the PTHmax in these rabbits was $45.6 \pm 7.4 \mathrm{pg} / \mathrm{ml}$. In rabbits from Group III, baseline $\mathrm{Ca}^{2+}$ was elevated $(2.06 \pm 0.06 \mathrm{mM})$ for 1 month. The PTH response to hypocalcemia in Group III was esentially the same as in Group I and PTHmax reached levels of $94.8 \pm 9.9 \mathrm{pg} / \mathrm{ml}$.

Conclusions: A difference in PTH response to hypocalcemia has been found in rabbits after exposure to either acute or chronic hypercalcemia. After acute hypercalcemia, an attenuated PTH response to hypocalcemia has been identified. Chronic hypercalcemia, however, did not influence the PTH response to hypocalcemia.
\end{abstract}

European Journal of Endocrinology 146 411-418

\section{Introduction}

The relationship between parathyroid hormone (PTH) and blood ionized calcium $\left(\mathrm{Ca}^{2+}\right)$ is best represented by a sigmoidal curve: the PTH- $\mathrm{Ca}^{2+}$ curve. The parathyroid glands have evolved to allow a wide range of response to hypocalcemia and thus basal PTH secretion is uniquely positioned at approximately $25 \%$ of the maximal PTH in normal humans and in most mammals $(1,2)$.

In a previous study, we reported a reduced PTH response to hypocalcemia after a short period of hypercalcemia. In these experiments, dogs were subjected to a hypercalcemic clamp $(1.65 \mathrm{mM})$ for $2 \mathrm{~h}$ and then their parathyroid glands were stimulated by reducing blood $\mathrm{Ca}^{2+}$. When compared with dogs in which hypocalcemia was initiated from basal $\mathrm{Ca}^{2+}(1.25 \mathrm{mM})$, the PTH response to hypocalcemia was less for the same $\mathrm{Ca}^{2+}$ when the reduction in $\mathrm{Ca}^{2+}$ was initiated from hypercalcemia than from a normal plasma calcium concentration (3).
This study raised the question of whether the parathyroid glands would also have a reduced response to hypocalcemia when exposed to chronic hypercalcemia. It is likely that some of the changes in PTH metabolism that have been described when parathyroid glands are exposed to acute hypercalcemia $(4,5)$ will also be present in chronic hypercalcemia (6). Moreover, chronic hypercalcemia has been reported to influence PTH gene transcription and decrease PTH mRNA levels (7, $8)$. Thus, theoretically, chronic hypercalcemia should also decrease the PTH response to hypocalcemia. However, it is also possible that over time the parathyroid glands become adapted to high levels of extracellular $\mathrm{Ca}^{2+}$.

To answer this question an animal model in which chronic hypercalcemia could be maintained was needed. Rabbits are known to have higher levels of extracellular $\mathrm{Ca}^{2+}$ than most mammals (around $1.7 \mathrm{mM}$ ). However, Butters et al. (9) have demonstrated that the intrinsic functional properties of the rabbit calcium-sensing receptor $(\mathrm{CaR})$ are indistinguishable 
from those observed in the human CaR. It seems that, in rabbits, the set-point for control of parathyroid function by $\mathrm{Ca}^{2+}$ is positioned to defend a $\mathrm{Ca}^{2+}$ concentration that would be high in most species (10). It is also documented that, in rabbits, chronic renal failure (CRF) results in a further increase in extracellular $\mathrm{Ca}^{2+}$ when dietary calcium is unrestricted (11). Thus, the rabbit with CRF would be an appropriate model in which to study the effect of chronic hypercalcemia on the PTH response to hypocalcemia.

The objective of the present study was to investigate the PTH response to hypocalcemia in normal rabbits and in rabbits in which hypercalcemia was induced either acutely (hypercalcemic clamp) or chronically (CRF).

\section{Materials and methods}

\section{Animals}

White New Zealand rabbits of both sexes, aged 9-15 months and weighing $3.8 \pm 0.1 \mathrm{~kg}$, were used in the experiments. They were housed individually, had permanent access to water and were fed ad libitum a commercial diet containing $\mathrm{Ca}=1.2 \%$ and $\mathrm{P}=0.6 \%$. They were randomly assigned to one of three groups. Group I $(n=10)$ : these animals were used as a control to obtain the PTH- $\mathrm{Ca}^{2+}$ curve in normocalcemic rabbits (plasma $\mathrm{Ca}^{2+}=1.7 \mathrm{mM}$ ). The $\mathrm{PTH}-\mathrm{Ca}^{2+}$ curve was also obtained in an additional group of normal rabbits, Group IB $(n=5)$, in which the rate of calcium reduction was modified to achieve lower levels of $\mathrm{Ca}^{2+}$ at the end of the experiments. Group II $(n=9)$ : in these rabbits, an acute $(2 \mathrm{~h})$ hypercalcemic clamp was performed and afterwards the PTH response to hypocalcemia was evaluated. Plasma $\mathrm{Ca}^{2+}$ was increased from its baseline value $(1.7 \mathrm{mM})$ to $2.05 \mathrm{mM}$ during the first $30 \mathrm{~min}$ and then was maintained at an elevated level for an additional period of $90 \mathrm{~min}$. Group III $(n=8)$ : in this group, CRF was induced by performing a 5/6 nephrectomy, as a consequence of which the rabbits developed chronic hypercalcemia. Nephrectomy was completed in two stages: in the first stage $2 / 3$ of the cortical parenchyma of the left kidney was ablated, a week later a contralateral nephrectomy was performed. Hypocalcemia was induced after the rabbits had been in CRF and hypercalcemic (2.05 mM) for 4 weeks.

\section{PTH-Ca ${ }^{2+}$ curves}

PTH- $\mathrm{Ca}^{2+}$ curves were obtained by i.v. infusion of disodium EDTA. In all experimental groups, rabbits were anesthetized by a combination of ketamine (40 mg/kg; Ketolar, Parke-Davis SL, Barcelona, Spain) and midazolam $(1 \mathrm{mg} / \mathrm{kg}$; Midazolam Rovi, Rovi SA, Madrid, Spain). The marginal auricular vein and the central auricular artery were cannulated with 24 gauge catheters. The venous port was used for EDTA infusion and the arterial side for blood sampling. The protocols for induction of hypocalcemia were as follows. Group I: EDTA infusion was initiated at a rate of $50 \mathrm{mg} / \mathrm{kg}$ per h. To achieve a linear decrease in $\mathrm{Ca}^{2+}$, the rate of the EDTA infusion was progressively increased every $5 \mathrm{~min}$, up to $190 \mathrm{mg} / \mathrm{kg}$ per h at the end of the experiment (30 min). In Group IB, the initial rate of EDTA was also $50 \mathrm{mg} / \mathrm{kg}$ per $\mathrm{h}$ and the rate of infusion was increased more rapidly so that the final rate was $400 \mathrm{mg} / \mathrm{kg}$ per h. Group II: in this group, a hypercalcemic clamp was performed before inducing hypocalcemia. Hypercalcemia was achieved by i.v. infusion of $\mathrm{CaCl}_{2}$ at a mean rate of $1.5 \mathrm{mEq} / \mathrm{kg}$ per $\mathrm{h}$ for $30 \mathrm{~min}$ and was then maintained for 90 additional min by infusing $\mathrm{CaCl}_{2}$ at a rate of $1.2 \mathrm{mEq} / \mathrm{kg}$ per $\mathrm{h}$. After $120 \mathrm{~min}$ with hypercalcemia, hypocalcemia was induced, first by reducing the dose of $\mathrm{CaCl}_{2}$ over $15 \mathrm{~min}$ and then by infusing EDTA at an initial rate of $25 \mathrm{mg} / \mathrm{kg}$ per $\mathrm{h}$ which was progressively increased to $240 \mathrm{mg} / \mathrm{kg}$ per $\mathrm{h}$ at the end of the experiment $(60 \mathrm{~min})$. Group III: basal calcium $(2.05 \mathrm{mM})$ was reduced by an EDTA infusion that was initiated at a rate of $50 \mathrm{mg} / \mathrm{kg}$ per $\mathrm{h}$ and increased every $5 \mathrm{~min}$ up to a final rate of $450 \mathrm{mg} / \mathrm{kg}$ per $\mathrm{h}$ at the end of the experiment (60 min).

Three blood samples were obtained from each animal as baseline; subsequently, blood samples were collected every $5 \mathrm{~min}$ throughout the experiments. Samples were immediately centrifuged. Plasma was separated and $\mathrm{Ca}^{2+}$ and $\mathrm{pH}$ were measured using selective electrodes (Ciba-Corning Diagnostics, Madrid, Spain); plasma was then frozen at $-70^{\circ} \mathrm{C}$. PTH was measured on plasma samples within 3 months of collection using an immunoradiometric assay which has been previously validated for quantitation of rabbit PTH (Allegro Intact PTH; Nichols, San Juan Capistrano, CA, USA) (10).

Plasma concentrations of creatinine, calcitriol (CTR) and phosphate were also measured in baseline samples. Creatinine and phosphate were quantified by spectrophotometric methods (Sigma Diagnostics, St Louis, MO, USA). CTR was measured using a radioreceptor assay (Immunodiagnostic Systems, Bolton, UK).

Individual $\mathrm{PTH}-\mathrm{Ca}^{2+}$ curves were constructed by adjusting the PTH and $\mathrm{Ca}^{2+}$ values of every rabbit to a sigmoidal equation. PTH concentrations at standardized $\mathrm{Ca}^{2+}$ levels (from $\mathrm{Ca}^{2+}=1 \mathrm{mM}$ to $\mathrm{Ca}^{2+}=2.05 \mathrm{mM}$, with an interval of $0.05 \mathrm{mM}$ ) were extrapolated from these individual curves. Mean PTH values at standardized $\mathrm{Ca}^{2+}$ concentrations were used to obtain the $\mathrm{PTH}-\mathrm{Ca}^{2+}$ curve for each group.

\section{Statistics}

For the intra- or intergroup comparison of three or more samples, repeated analysis of variance (ANOVA) was used. If the ANOVA showed a statistical 
difference, a post hoc test, the Fisher least significance difference test, was used to determine differences. A $P$ value $<0.05$ was considered significant. Results are expressed as the means \pm S.E.

\section{Results}

Table 1 shows parameters related with renal function in normal rabbits (Groups I and II) and rabbits with CRF (Group III). Plasma creatinine concentration was significantly higher in rabbits with CRF than in normal rabbits $(3.8 \pm 0.6$ vs $0.9 \pm 0.1 \mathrm{mg} / \mathrm{dl}, P<0.001)$. Rab-

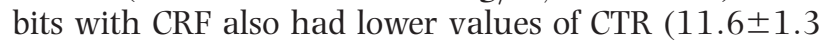
vs $52.4 \pm 4.1 \mathrm{pg} / \mathrm{ml}, \quad P<0.001)$ and phosphate (2.3 \pm 0.2 vs $3.3 \pm 0.2 \mathrm{mg} / \mathrm{dl}, P=0.011)$. No differences in plasma $\mathrm{pH}$ were detected between normal and uremic rabbits $(7.421 \pm 0.007$ vs $7.423 \pm 0.012$, not significant (NS)).

The time-course for plasma $\mathrm{Ca}^{2+}$ and PTH in Groups I, II and III is presented in Fig. 1. In Group I, EDTA infusion caused a progressive decline in plasma $\mathrm{Ca}^{2+}$ from its baseline concentration of $1.69 \pm 0.02 \mathrm{mM}$ to $1.34 \pm 0.04 \mathrm{mM}$ at the end of the experiment (Fig. 1A). Hypocalcemia resulted in a steady increase in PTH secretion: plasma PTH levels rose from a basal value of $31.5 \pm 6.1 \mathrm{pg} / \mathrm{ml}$ to a maximum (PTHmax) of $91.7 \pm 6.4 \mathrm{pg} / \mathrm{ml}$ (Fig. 1B).

Rabbits from Group II had a basal plasma $\mathrm{Ca}^{2+}$ similar to Group I (1.70 \pm 0.02 vs $1.69 \pm 0.02 \mathrm{mM}, \mathrm{NS})$. In these rabbits, $\mathrm{CaCl}_{2}$ infusion increased the plasma $\mathrm{Ca}^{2+}$ over $30 \mathrm{~min}$ to a value of $2.11 \pm 0.03 \mathrm{pg} / \mathrm{ml}$; during the following $90 \mathrm{~min}$, the plasma $\mathrm{Ca}^{2+}$ was clamped at levels around $2.05 \mathrm{mM}$. EDTA was then infused and plasma $\mathrm{Ca}^{2+}$ was decreased from $2.04 \pm 0.03$ to $0.95 \pm 0.03 \mathrm{mM}$ in a 60 -min period (Fig. 1A). Basal PTH concentration was not different

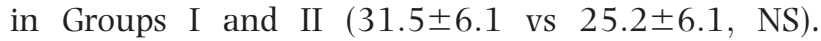
During the hypercalcemic clamp, PTH concentration was significantly reduced to levels around $6 \mathrm{pg} / \mathrm{ml}$. The subsequent hypocalcemia produced a moderate increase in PTH concentration which rose from $7.5 \pm 0.1 \mathrm{pg} / \mathrm{ml}$ to only $45.6 \pm 7.4 \mathrm{pg} / \mathrm{ml}$ (Fig. 1B).

Group III rabbits had a basal $\mathrm{Ca}^{2+}$ of $2.06 \pm 0.06 \mathrm{mM}$; this $\mathrm{Ca}^{2+}$ level was significantly higher than the basal $\mathrm{Ca}^{2+}$ in Groups I and II (1.69 \pm 0.02 and
$1.70 \pm 0.02 \mathrm{mM}, \mathrm{P}<0.001)$ and similar to the $\mathrm{Ca}^{2+}$ concentration at the end of the hypercalcemic clamp in Group II $(2.04 \pm 0.03 \mathrm{mM}, P=0.602)$. During EDTA infusion, plasma $\mathrm{Ca}^{2+}$ was reduced over $60 \mathrm{~min}$ to reach a final concentration of $0.95 \pm 0.04 \mathrm{mM}$ (Fig. 1A). Baseline PTH in Group III rabbits $(2.2 \pm 0.3 \mathrm{pg} / \mathrm{ml})$ was significantly lower than in Groups I $(31.5 \pm 6.1 \mathrm{pg} / \mathrm{ml}, \quad P=0.004)$ and II (25.2 $\pm 6.1 \mathrm{pg} / \mathrm{ml}, \quad P=0.04)$. During hypocalcemia, the PTH levels increased steadily up to $94.8 \pm$ $9.9 \mathrm{pg} / \mathrm{ml}$ (Fig. 1B).

When studying the $\mathrm{PTH}-\mathrm{Ca}^{2+}$ curve obtained in rabbits from Group I, at the standardized $\mathrm{Ca}^{2+}$ level that was closest to basal calcium $(1.70 \mathrm{mM})$, the PTH concentration was $26.9 \pm 4.2 \mathrm{pg} / \mathrm{ml}$. Hypocalcemia caused an increase in PTH concentration up to a maximum of $91.7 \pm 6.4 \mathrm{pg} / \mathrm{ml}$ which was achieved with a $\mathrm{Ca}^{2+}$ concentration of $1.35 \mathrm{mM}$. In Group II, in which the hypocalcemic stimulus was initiated from hypercalcemia, the PTH concentration for a standardized $\mathrm{Ca}^{2+}$ level of $2.05 \mathrm{mM}$ was $4.1 \pm 0.5 \mathrm{pg} / \mathrm{ml}$. During hypocalcemia, PTH secretion was stimulated; however, at baseline $\mathrm{Ca}^{2+}(1.7 \mathrm{mM})$, PTH concentration was slightly lower than in Group I (17.5 \pm 1.3 vs $26.9 \pm 4.2, P=0.19)$ and further reductions in $\mathrm{Ca}^{2+}$ resulted in only a moderate increase in PTH that reached a maximum around $40 \mathrm{pg} / \mathrm{ml}$ at a $\mathrm{Ca}^{2+}$ level of $1.25 \mathrm{mM}$. A further decrease in plasma $\mathrm{Ca}^{2+}$ did not elicit an increase in PTH secretion. Moreover, within the $\mathrm{Ca}^{2+}$ concentration range of 1.65-1.0 mM, the PTH concentration was significantly lower in Group II than in Group I (Fig. 1C).

In Group III, the PTH-Ca ${ }^{2+}$ curve was initiated from the baseline hypercalcemic values. PTH concentration increased from a level below $2 \mathrm{pg} / \mathrm{ml}$, at $\mathrm{Ca}^{2+}=$ $2.05 \mathrm{mM}$, to $24.6 \pm 4.5 \mathrm{pg} / \mathrm{ml}$, at $\mathrm{Ca}^{2+}=1.7 \mathrm{mM}$. There were no differences in the PTH concentration at this $\mathrm{Ca}^{2+}$ level between Groups I and III (25.2 \pm 4.2 vs $24.6 \pm 4.5 \mathrm{pg} / \mathrm{ml}$, NS). The $\mathrm{PTH}-\mathrm{Ca}^{2+}$ curve at $\mathrm{Ca}^{2+}$ concentrations below $1.7 \mathrm{mM}$ was very similar in Groups I and III, and no significant differences were detected between these two groups at any $\mathrm{Ca}^{2+}$ level (Fig. 1C).

A summary of the changes in $\mathrm{Ca}^{2+}$ and PTH in the three experimental Groups (I, II and III) is shown in Table 2.

Table 1 Biochemical parameters (means \pm S.E.) in normal rabbits (Groups I and II) and rabbits with CRF (Group III).

\begin{tabular}{lcccc}
\hline & $\begin{array}{c}\text { Creatinine } \\
(\mathrm{mg} / \mathrm{dl})\end{array}$ & $\begin{array}{c}\text { CTR } \\
(\mathrm{pg} / \mathrm{ml})\end{array}$ & $\begin{array}{c}\text { Phosphate } \\
(\mathrm{mg} / \mathrm{dl})\end{array}$ & pH \\
\hline Normal rabbits $(n=19)$ & $0.9 \pm 0.1$ & $52.4 \pm 4.1$ & $3.3 \pm 0.2$ & $7.421 \pm 0.007$ \\
CRF rabbits $(n=8)$ & $3.8 \pm 0.6^{*}$ & $11.6 \pm 1.3^{*}$ & $2.3 \pm 0.2^{*}$ & $7.423 \pm 0.012$ \\
\hline
\end{tabular}

CRF, chronic renal failure; CTR, calcitriol.

${ }^{*} P<0.05$ vs normal rabbits. 

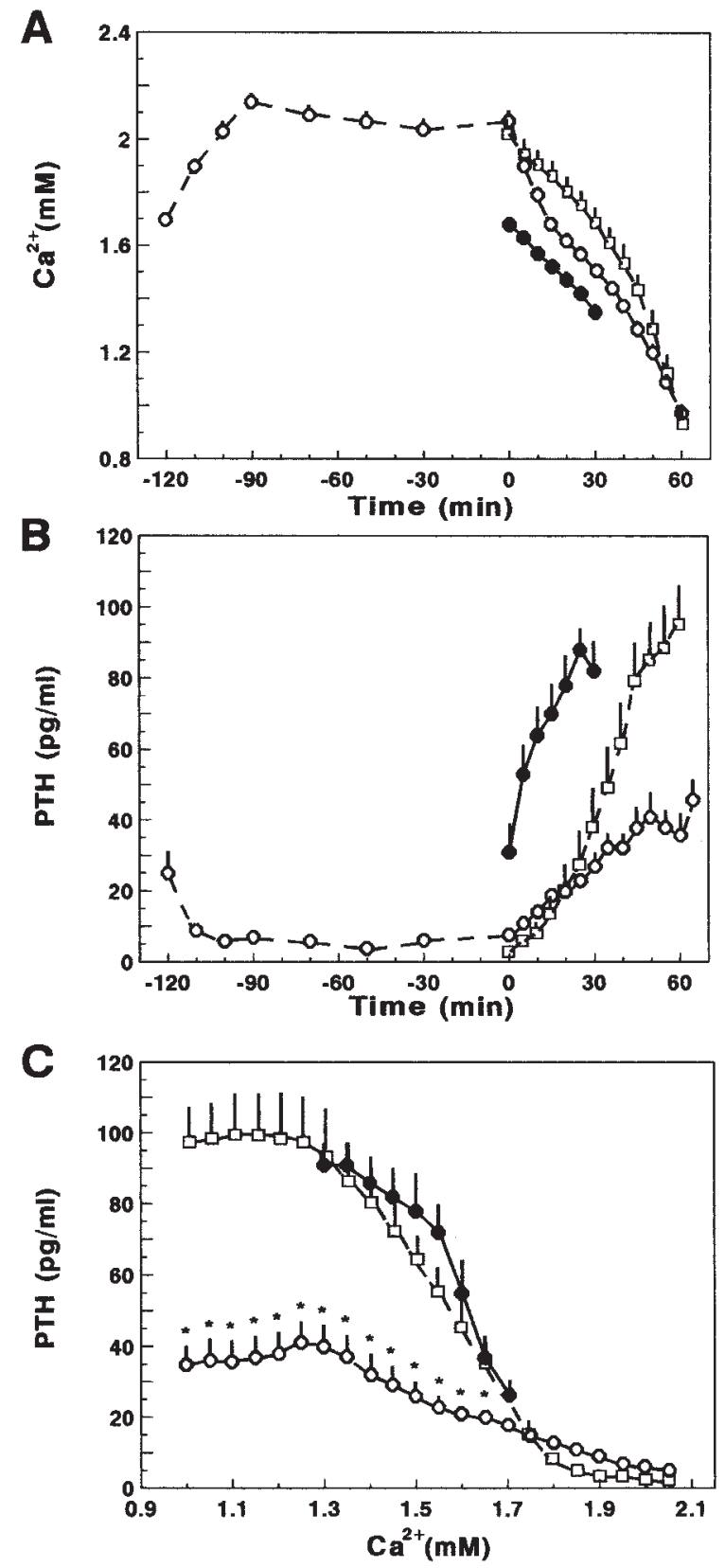

Figure 1 The time-course of $\mathrm{Ca}^{2+}(\mathrm{A})$ and PTH $(\mathrm{B})$ and the PTH $-\mathrm{Ca}^{2+}$ curve (C) in Groups I, II and III. Values are the means \pm S.E. (when the standard error bar is not present, it was too small to draw). Normocalcemic rabbits (Group I (๑)), rabbits with acute hypercalcemic clamp (Group II (O)) and chronic hypercalcemic rabbits (Group III $(\square)$ ). ${ }^{*} P<0.05$, significant differences in PTH concentration, for the same $\mathrm{Ca}^{2+}$ level, with respect to Group I. All the PTH values corresponding to $\mathrm{Ca}^{2+}$ concentrations below $1.35 \mathrm{mM}$ of Groups II and III have been compared with the maximum PTH value in Group I.

A comparative study of the hypercalcemic part of the $\mathrm{PTH}-\mathrm{Ca}^{2+}$ curve in Groups II and III is presented in Fig. 2. At a standardized $\mathrm{Ca}^{2+}=2.05 \mathrm{mM}$, the PTH concentration was significantly lower in Group III than

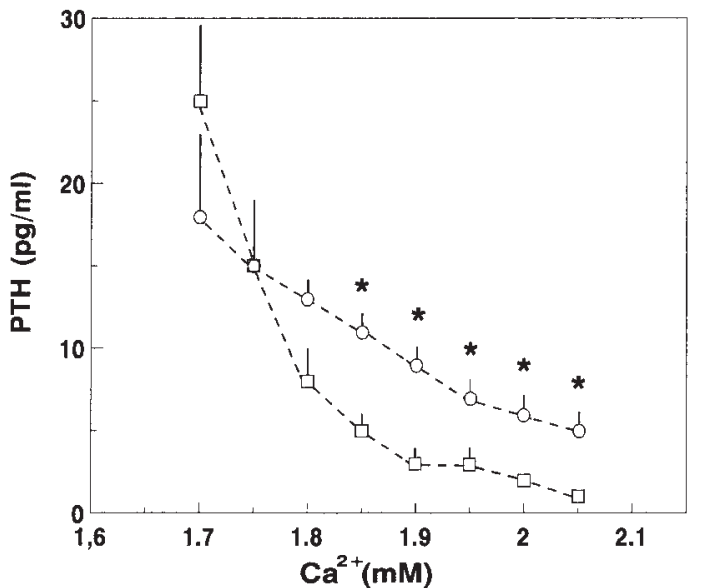

Figure 2 The hypercalcemic part of the $\mathrm{PTH}-\mathrm{Ca}^{2+}$ curve in Groups II and III. Values are the mean \pm S.E. Rabbits with acute hypercalcemic clamp (Group II (O)) and chronic hypercalcemic rabbits (Group III $(\square)$ ). * $P<0.05$, significant differences between groups.

in Group II $(1.3 \pm 0.3$ vs $5.1 \pm 0.6 \mathrm{pg} / \mathrm{ml}, P<0.001)$. PTH concentrations remained significantly lower in Group III than in Group II at $\mathrm{Ca}^{2+}$ levels ranging from 2.05 to $1.85 \mathrm{mM}$. The PTH levels became similar in both groups at $\mathrm{Ca}^{2+}=1.75 \mathrm{mM}$ and, at the standardized $\mathrm{Ca}^{2+}$ level that is closest to the basal $\mathrm{Ca}^{2+}$ of normal rabbits $(1.70 \mathrm{mM})$, the PTH concentration was slightly higher in Group III than in Group II.

A comparison of the time-course of $\mathrm{Ca}^{2+}$ in Groups I and III (Fig. 1) revealed that the final $\mathrm{Ca}^{2+}$ concentration was higher in Group I than in Group III. To exclude the possibility that this difference might have influenced the results, an additional control group (Group IB) was studied. Figure 3 shows the timecourse of $\mathrm{Ca}^{2+}$ and PTH in Groups IB and III. In Group IB, the reduction of $\mathrm{Ca}^{2+}$, from 1.64 to $0.85 \mathrm{mM}$, was achieved in $30 \mathrm{~min}$. Thus, the rate of $\mathrm{Ca}^{2+}$ reduction was similar in Groups IB and III (Fig. $3 \mathrm{~A})$. Baseline $\mathrm{Ca}^{2+}$ concentration was slightly lower in Group IB than in Group I ( $1.64 \pm 0.03$ vs $1.69 \pm$ $0.02 \mathrm{mM}$ ) and this also resulted in higher basal PTH levels $(49.3 \pm 12.8$ vs $31.5 \pm 6.1 \mathrm{pg} / \mathrm{ml})$; however, these differences were not statistically significant. The changes in PTH in Group IB were practically identical to the changes in Group III, and there was no difference in the maximal PTH concentration observed in Groups IB and III (Fig. 3B). Moreover, the PTH $-\mathrm{Ca}^{2+}$ curves were similar in Groups IB and III, and no significant differences in PTH concentration were found at any $\mathrm{Ca}^{2+}$ level (Fig. 3C).

\section{Discussion}

The objective of the present study was to investigate whether the PTH response to hypocalcemia was 
Table 2 Changes in $\mathrm{Ca}^{2+}$ and PTH in the three groups of rabbits (Group I = normal rabbits, Group II = normal rabbits subjected to a hypercalcemic clamp, Group III = rabbits with chronic hypercalcemia secondary to CRF). Values are means \pm S.E..

\begin{tabular}{lllll}
\hline & $\mathrm{Ca}^{2+}(\mathrm{b})(\mathrm{mM})$ & $\mathrm{PTH}(\mathrm{b})(\mathrm{pg} / \mathrm{ml})$ & $\mathrm{Ca}^{2+}(\mathrm{min})(\mathrm{mM})$ & $\mathrm{PTHmax}(\mathrm{pg} / \mathrm{ml})$ \\
\hline Group I $(n=10)$ & $1.69 \pm 0.02$ & $31.5 \pm 6.1$ & $1.34 \pm 0.04$ & $91.7 \pm 6.4^{\mathrm{b}}$ \\
Group II $(n=8)$ & $2.04 \pm 0.03^{\mathrm{a}}$ & $7.5 \pm 0.1^{\mathrm{a}}$ & $0.95 \pm 0.03^{\mathrm{a}}$ & $45.6 \pm 7.4^{\mathrm{a}}$ \\
Group III $(n=9)$ & $2.06 \pm 0.06^{\mathrm{a}}$ & $2.2 \pm 0.3^{\mathrm{a}, \mathrm{b}}$ & $0.95 \pm 0.04^{\mathrm{a}}$ & $94.8 \pm 9.9^{\mathrm{b}}$ \\
\hline
\end{tabular}

$\mathrm{Ca}^{2+}(\mathrm{b})=$ plasma calcium concentration at the beginning of the hypocalcemic stimulus. $\mathrm{PTH}(\mathrm{b})=$ plasma PTH concentration at the beginning of the hypocalcemic stimulus. $\mathrm{Ca}^{2+}(\mathrm{min})=$ plasma calcium conentration that elicited maximal stimulation of PTH secretion. PTHmax = maximum value of PTH obtained during the hypocalcemic stimulation of the parathyroid glands.

${ }^{\mathrm{a} P}<0.05$ vs Group I. ${ }^{\mathrm{b}} P<0.05$ vs Group II.

attenuated after the parathyroid glands had been exposed to chronic (1 month) hypercalcemia. Our results show that in contrast to acute hypercalcemia, which causes an attenuated PTH response to hypocalcemia, chronic hypercalcemia does not influence the PTH response to hypocalcemia.

In this study, the rabbit with CRF has been chosen as an animal model for chronic hypercalcemia. This model is convenient because hypercalcemia can be achieved without providing exogenous PTH or CTR supplementation. In normal rabbits on a standard diet, the plasma $\mathrm{Ca}^{2+}$ concentration is around $1.7 \mathrm{mM}$. This value, although relatively high as compared with most species, is normal for rabbits as reflected by the fact that PTH secretion in these animals, far from being inhibited, is approximately $25 \%$ of PTHmax. Moreover, the PTH response obtained in normal rabbits after an acute hypercalcemic clamp is similar to that which has been previously observed in dogs (3). Thus, the higher $\mathrm{Ca}^{2+}$ values in normal rabbits should not interfere with the objective of this work.

The mechanisms responsible for chronic hypercalcemia in rabbits with CRF are not clear. It is interesting to note that the horse, another mammal with a relatively high extracellular calcium, also develops hypercalcemia during CRF (12). Moreover, both species show a tendency to decreased plasma phosphate levels in conjunction with hypercalcemia $(11,12)$. These biochemical changes seem to be related to the fact that rabbits and horses have a higher net intestinal absorption of calcium than most mammals, and to maintain calcium homeostasis they rely, to a large extent, on renal excretion of calcium (fractional excretion of calcium can reach levels of $45 \%$, as compared with values of $2 \%$ in other species). Thus it is likely that during CRF, if calcium intake is unrestricted, these animals fail to excrete the relatively high load of calcium absorbed in the intestine and develop hypercalcemia $(11,12)$.

In normal rabbits (Group I), baseline $\mathrm{Ca}^{2+}$ values and the PTH $-\mathrm{Ca}^{2+}$ curve were within the range reported in the literature $(10,13,14)$. It is interesting to note that although plasma $\mathrm{Ca}^{2+}$ concentration in rabbits is higher than in most mammals, PTH values are com- parable with those which have been reported in man, carnivores and rodents $(1,15,16)$. This is not a unique feature of rabbits since in the horse, another mammal with high basal $\mathrm{Ca}^{2+}$ levels, PTH values have also been reported to be within the normal range of normocalcemic animals (17).

The results obtained during the hypercalcemic clamp (Group II) were also similar to those previously reported using the same protocol in dogs (3). However, as compared with the results obtained by Sánchez et al. (3) there are two points that should be noted. (a) The PTH response to hypocalcemia is even more attenuated after the hypercalcemic clamp in rabbits (50\% of PTHmax) that in dogs (60\% of PTHmax) and (b) in the study by Sánchez et al. (3) PTH secretion never reached a plateau, although the final $\mathrm{Ca}^{2+}$ was $0.8 \mathrm{mM}\left(\Delta \mathrm{Ca}^{2+}=0.8 \mathrm{mM}\right)$. Thus, in that study, there was a possibility that further reductions in $\mathrm{Ca}^{2+}$ may have resulted in a progressive increase in PTH to reach PTHmax. In our rabbits, however, PTH reached a maximum at $\mathrm{Ca}^{2+}=1.25 \mathrm{mM}$ and then remained stable at around $40 \mathrm{pg} / \mathrm{ml}$, despite the fact that $\mathrm{Ca}^{2+}$ was decreased to $1.0 \mathrm{mM}$. In some rabbits, $\mathrm{Ca}^{2+}$ was lowered further, to $0.8 \mathrm{mM}$, and PTH continued at the same plateau (data not shown).

The reasons for the reduced PTH response to hypocalcemia after a short period of hypercalcemia are not clear. High levels of extracellular $\mathrm{Ca}^{2+}$ have been shown to promote intracellular PTH degradation both in vivo (5) and in vitro (4), thus an increase in intracellular PTH metabolism could be a major factor in the reduced PTH response to hypocalcemia found in Group II. Likewise, an elevation in extracellular $\mathrm{Ca}^{2+}$ concentration has also been shown to inhibit PTH biosynthesis by decreasing levels of PTH mRNA $(7,8)$. However, the decrease in PTH mRNA begins after $16 \mathrm{~h}$ of exposure to high $\mathrm{Ca}^{2+}{ }^{(7)}$; therefore changes in PTH synthesis are probably not relevant in our acute $(2 \mathrm{~h})$ experiments. It has also been speculated that secretory products could modify the PTH response to changes in plasma $\mathrm{Ca}^{2+}$. In this context, it has been shown that, during hypercalcemia, secretion of intact PTH(1-84) is suppressed while secretion of carboxyterminal PTH is less suppressed (18-20). In addition 

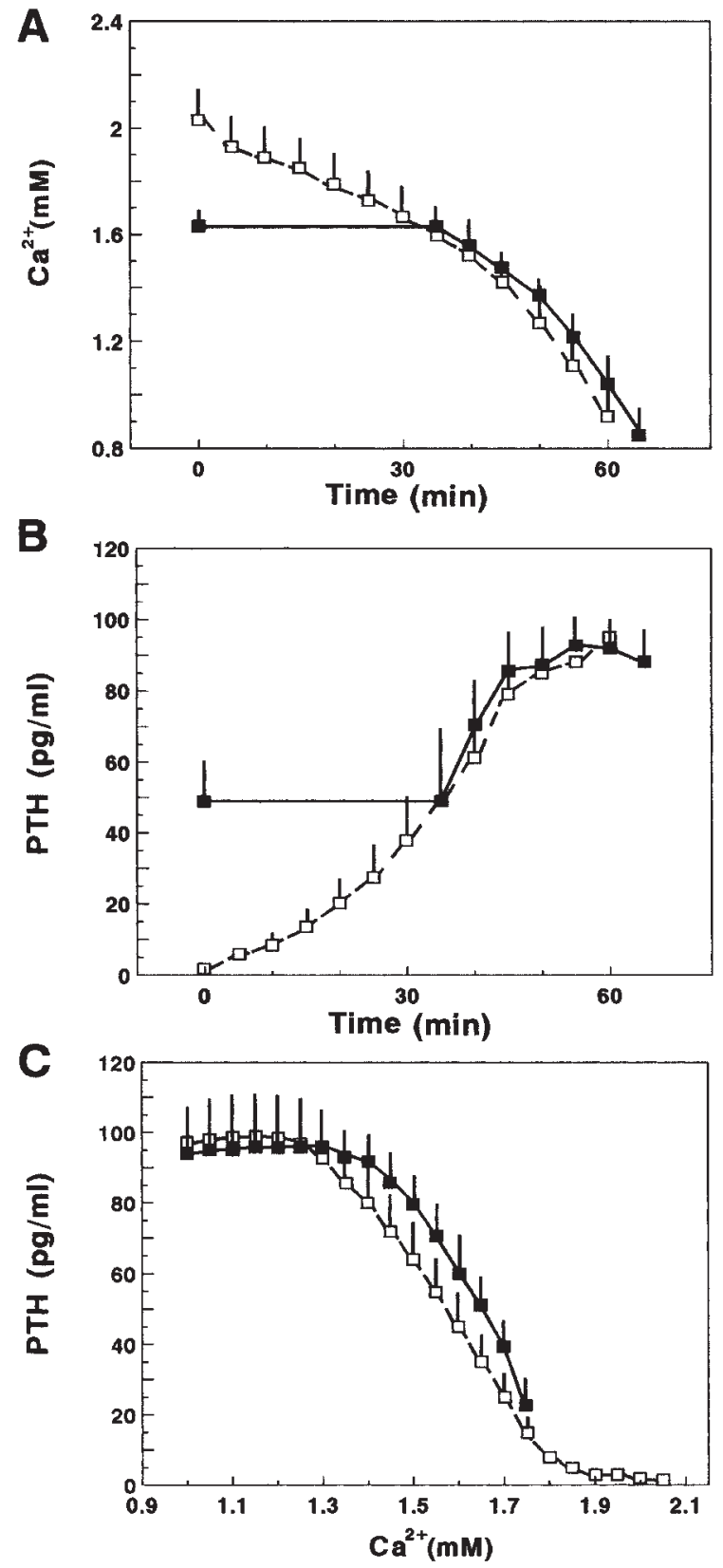

Figure 3 The time-course of $\mathrm{Ca}^{2+}(\mathrm{A})$ and PTH $(\mathrm{B})$ and the PTH- $\mathrm{Ca}^{2+}$ curve (C) in Groups IB and III are shown. Values are the means \pm S.E. (when the standard error bar is not present, it was too small to draw). Normocalcemic rabbits (Group IB (ם)) and chronic hypercalcemic rabbits (Group III ( $\square)$ ).

to the secretion of intact PTH and its fragments, several secretory products of the parathyroid glands like chromogranin A and its metabolites (21-23) and endothelin 1 (24) could play a role in the inhibition of PTH secretion after acute hypercalcemia. Finally, changes in intracellular sensing mechanisms triggered by the action of calcium on the $\mathrm{CaR}$ could also explain this phenomenon - 90 min of sustained hypercalcemia may alter intracellular signaling (concentration of intracellular mediators, such as arachidonic acid) (25) resulting in a blunted secretory response to subsequent hypocalcemia.

This study was designed to test the hypothesis that chronic hypercalcemia would result in a decrease in the PTH response to hypocalcemia, similar to that previously described after acute hypercalcemia (3). However, the results obtained in Group III rabbits proved this hypothesis not to be true.

Since PTHmax did not decrease after 1 month with hypercalcemia, the size of the parathyroid glands was presumably unchanged during this period of time. However, basal PTH concentrations were very low in Group III rabbits. Thus, it is likely that the percentage of secretory cells was reduced during chronic hypercalcemia. This hypothesis, i.e. an increase in the percentage of cells that are capable of secretion but do not release PTH at baseline $\mathrm{Ca}^{2+}$, would be in agreement with the heterogeneous response to changes in extracellular $\mathrm{Ca}^{2+}$ by individual parathyroid cells described by Sun et al. (26).

It is also interesting to note that when comparing PTH secretion in hypercalcemia (between $\mathrm{Ca}^{2+} 2.05$ and $1.70 \mathrm{mM}$ ) in Groups II and III (Fig. 2), PTH levels are significantly higher in Group II (acute hypercalcemia) than in Group III (chronic hypercalcemia). This fact could be explained by the hysteresis of the PTH $-\mathrm{Ca}^{2+}$ curve. With respect to the PTH- $\mathrm{Ca}^{2+}$ relationship, the term hysteresis indicates that for the same plasma $\mathrm{Ca}^{2+}$, the plasma PTH is lower during the acute induction of hypercalcemia than the acute recovery from hypercalcemia (27). Thus, in Group II rabbits, which have normal baseline $\mathrm{Ca}^{2+}(1.70 \mathrm{mM})$ and are recovering from an acute hypercalcemia, the hysteresis of the PTH- $\mathrm{Ca}^{2+}$ curve would increase PTH levels. This phenomenom is not observed in Group III rabbits which had been hypercalcemic (baseline $\mathrm{Ca}^{2+}=2.06 \pm 0.06 \mathrm{mM}$ ) for 1 month.

When this study was designed, a reduction in $\mathrm{Ca}^{2+}$ concentration $\left(\Delta \mathrm{Ca}^{2+}\right)$ of $0.4 \mathrm{mM}$ (from 1.7 to $1.3 \mathrm{mM}$ ) over a period of $30 \mathrm{~min}$ was considered appropriate to obtain the $\mathrm{PTH}-\mathrm{Ca}^{2+}$ curve in normal rabbits (Group I). This degree of hypocalcemia is known to maximally stimulate PTH secretion in all the species in which PTH-Ca ${ }^{2+}$ curves have been reported $(1,2$, $3,17)$ including rabbits (10). In Groups II and III, in which a reduced PTH response to hypocalcemia was anticipated, $\mathrm{Ca}^{2+}$ levels were further reduced, reaching a final $\mathrm{Ca}^{2+}$ concentration below $1.0 \mathrm{mM}$. Although the results obtained in Group I indicate that the maximum of PTH secretion had been attained (no significant changes in PTH concentration were detected in the last two samples even though there was a significant reduction in $\mathrm{Ca}^{2+}$ ), it was decided to include a second control group of normal rabbits (Group IB) in which $\mathrm{Ca}^{2+}$ concentration was reduced to the same level as 
that in Groups II and III. The study of this additional group was meant to ensure that the PTH response to hypocalcemia was not significantly different in normal rabbits and in rabbits subjected to chronic hypercalcemia. As can be appreciated in Fig. 3, the reduction in plasma $\mathrm{Ca}^{2+}$ below $1.0 \mathrm{mM}$ did not increase the PTH response in normal rabbits. The PTH response to hypocalcemia was practically identical in Groups IB and III, thus confirming the results obtained in Group I and providing support for the hypothesis that chronic hypercalcemia does not modify the PTH response to hypocalcemia.

The difference between the parathyroid response to hypocalcemia after acute versus chronic hypercalcemia could be explained by the disappearence over time of any kind of regulation that would serve to explicate the reduced response to hypocalcemia after acute hypercalcemia. The signaling system coupled to the CaR may be adapted to chronic hypercalcemia; thus, despite a high ambient calcium which inhibits PTH secretion, the secretory response to hypocalcemia is normal. It is also possible that the changes induced by acute hypercalcemia persist during chronic hypercalcemia but may be compensated by the effect of the decreased CTR levels found in rabbits with CRF. A decrease in CTR is known to stimulate PTH synthesis and secretion (28-30) and thus could counteract the inhibitory effect of hypercalcemia. If this were the case, the influence of decreased CTR should be evident at any calcium level. While a decrease in CTR could serve to explain the normal PTH response to hypocalcemia in chronic hypercalcemic rabbits, it would be reasonable to expect that these rabbits also had increased PTH levels during hypercalcemia. However, as shown in Fig. 2, the PTH concentration at high $\mathrm{Ca}^{2+}$ levels $(1.7-2.05 \mathrm{mM})$ in chronic hypercalcemic rabbits with decreased CTR is inferior to the PTH concentration at the same $\mathrm{Ca}^{2+}$ levels in acute hypercalcemic rabbits with normal CTR.

It is also interesting to note that even though the PTH response to calcium (PTH-Ca ${ }^{2+}$ curve) in chronic hypercalcemic rabbits is not different from that in normocalcemic rabbits, the parathyroid glands do not sense the chronic high $\mathrm{Ca}^{2+}$ as normal $\mathrm{Ca}^{2+}$. This contention is supported by two facts. (a) At high $\mathrm{Ca}^{2+}$ levels PTH secretion is inhibited, actually it is maximally inhibited and (b) the parathyroid glands do not try to 'defend' this high $\mathrm{Ca}^{2+}$ level. If the glands were sensing the high $\mathrm{Ca}^{2+}$ as normal, they would respond with maximal stimulation to a significant reduction in $\mathrm{Ca}^{2+}$. However, when challenged with a decrease in $\mathrm{Ca}^{2+}$ that would produce maximal secretion in normocalcemic rabbits $\left(\Delta \mathrm{Ca}^{2+}=0.35 \mathrm{mM}\right), \mathrm{PTH}$ is not maximally stimulated but rather reaches the same concentration as in normocalcemic rabbits with $\mathrm{Ca}^{2+}=$ 1.70. These data indicate that in rabbits subjected to chronic hypercalcemia, PTH concentration is determined mainly by the actual $\mathrm{Ca}^{2+}$ level.
This study also provides information on the changes in mineral metabolism during CRF in rabbits. It has long been known that rabbits with CRF experience an increase in $\mathrm{Ca}^{2+}$; however, to our knowledge, the PTH response in rabbits with $\mathrm{CRF}$ had not been reported. Our results indicate that rabbits with CRF have suppressed basal PTH levels and did not develop secondary hyperparathyroidism over the time-course of this study. Hyperparathyroidism secondary to renal failure is caused by a decrease in CTR and $\mathrm{Ca}^{2+}$ and an increase in phosphate. In rabbits with CRF, although CTR is decreased, $\mathrm{Ca}^{2+}$ is increased and phosphate is decreased and the net result is a decrease in PTH concentration. These results emphasize the role of $\mathrm{Ca}^{2+}$ in the regulation of parathyroid gland function during CRF. In addition, it is interesting to note that the horse (another mammal with high basal $\mathrm{Ca}^{2+}$ that develops hypercalcemia during CRF) behaves similarly (31).

In conclusion, a difference in the PTH response to hypocalcemia has been found in rabbits after exposure to either acute or chronic hypercalcemia. After acute hypercalcemia, an attenuated PTH response to hypocalcemia, similar to that previously described in dogs, has been identified. Chronic hypercalcemia, however, did not influence the PTH response to hypocalcemia. These results suggest that rabbit parathyroid gland function is unchanged after chronic hypercalcemia.

\section{Acknowledgements}

This work was supported by grants PM97-0090 and PM99-0768 from the Dirección General de Enseñanza Superior, the Plan Andaluz de Investigación (Grupo CTS-179) and the Fundación Reina Sofía-Cajasur.

\section{References}

1 Brent GA, Leboff MS, Seely EW, Conlin PR \& Brown EM. Relationship between the concentration and rate of change of calcium and serum intact parathyroid hormone levels in normal humans. Journal of Clinical Endocrinology and Metabolism 1988 $67944-950$.

2 Mayer GP \& Hurst JG. Sigmoidal relationship between parathyroid hormone secretion rate and plasma calcium concentration in calves. Endocrinology $1978 \mathbf{1 0 2} 1036-1042$.

3 Sánchez J, Aguilera-Tejero E, Estepa JC, Almadén Y, Rodríguez M \& Felsenfeld AJ. A reduced PTH response to hypocalcemia after a short period of hypercalcemia: a study in dogs. Kidney International $1996 \mathbf{5 0}$ (Suppl 57) S18-S22.

4 Habener JF, Kemper B \& Potts JR. Calcium-dependent intracellular degradation of parathyroid hormone: a possible mechanism for the regulation of hormone stores. Endocrinology $1975 \mathbf{9 7}$ $431-441$.

5 Chu LLH, MacGregor RR, Anast CS, Hamilton JW \& Cohn DV. Studies on the biosynthesis of rat parathyroid hormone and proparathyroid hormone: adaptation of the parathyroid gland to dietary restriction of calcium. Endocrinology $1973 \mathbf{9 3}$ 915-924.

6 Brossard J-H, Whittom S, LePage R \& D'Amour P. Carboxylterminal fragments of parathyroid hormone are not secreted 
preferentially in primary hyperparathyroidism as they are in other hypercalcemic conditions. Journal of Clinical Endocrinology and Metabolism 199377 413-419.

7 Russell J, Lettieri D \& Sherwood LM. Direct regulation by calcium of cytoplasmic messenger ribonucleic acid coding for pre-proparathyroid hormone in isolated bovine parathyroid cells. Journal of Clinical Investigation $1983 \mathbf{7 2}$ 1851-1855.

8 Yamamoto M, Igarashi T, Muramatsu M, Fukagawa M, Motokura $\mathrm{T} \&$ Ogata E. Hypocalcemia increases and hypercalcemia decreases the steady-state level of parathyroid hormone messenger RNA in the rat. Journal of Clinical Investigation $1989 \mathbf{8 3}$ 1053-1056.

9 Butters RR, Chattopadhyay N, Nielsen P, Smith CP, Mithal A, Kifor $\mathrm{O}$ et al. Cloning and characterization of a calcium-sensing receptor from the hypercalcemic New Zealand White rabbit reveals unaltered responsiveness to extracellular calcium. Journal of Bone and Mineral Research 199712 568-579.

10 Warren HB, Lausen NCC, Segre GV, El-Hajj G \& Brown EM. Regulation of calciotropic hormones in vivo in the New Zealand White rabbit. Endocrinology 1989125 2683-2690.

11 Eddy AE, Falk RJ, Sibley RK \& Hostetter TH. Subtotal nephrectomy in the rabbit: A model of chronic hypercalcemia, nephrolithiasis, and obstructive nephropathy. Journal of Laboratory and Clinical Medicine $1986 \mathbf{1 0 7}$ 508-516.

12 Tennant B, Lowe JE \& Tasker JB. Hypercalcemia and hypophosphatemia in ponies following bilateral nephrectomy. Proceedings of the Society for Experimental Biology and Medicine $1981 \mathbf{1 6 7}$ $365-368$.

13 Tvedegaard E. Renal function and 1alpha-hydroxyvitamin $\mathrm{D}_{3}$ in rabbits with normal renal function and renal insufficiency. Scandinavian Journal of Urology and Nephrology $1983 \quad \mathbf{1 7}$ 373-376.

14 Yu L, Pragay DA, Chang D \& Wicher K. Biochemical parameters of normal rabbit serum. Clinical Biochemistry 197912 83-87.

15 Torrance AG \& Nachreiner R. Human-parathormone assay for use in dogs: validation, sample handling studies and parathyroid function testing. American Journal of Veterinary Research 198950 $1123-1127$

16 Jara A, Bover J, Lavigne J \& Felsenfeld A. Comparison of two parathyroid hormone assays for the rat: the new immunoradiometric and the older competitive binding assay. Journal of Bone and Mineral Research $1994101629-1633$.

17 Estepa JC, Aguilera-Tejero E, Mayer-Valor R, Almadén Y, Felsenfeld AJ \& Rodríguez M. Measurement of parathyroid hormone in horses. Equine Veterinary Journal 199830 476-481.

18 Cloutier M, Gascon-Barre M \& D'Amour P. Chronic adaptation of dog parathyroid function to a low-calcium-high-sodiumvitamin D-deficient diet. Journal of Bone and Mineral Research 19927 1021-1028.

19 Cloutier M, Brossard JH, Gascon-Barre M \& D'Amour P. Lack of involution of hyperplastic parathyroid glands in dogs: adaptation via a decrease in the calcium stimulation set point and a change in secretion profile. Journal of Bone and Mineral Research 19949 621-629.

20 Mayer GP, Keaton JA, Hurst JG \& Habener JF. Effects of plasma calcium concentration on the relative proportion of hormone and carboxyl fragments in parathyroid venous blood. Endocrinology $1979 \mathbf{1 0 4} 1778-1784$.

21 Ritchie CK, Cohn DV, Maercklein PB \& Fitzpatrick LA. Individual parathyroid cells exhibit cyclic secretion of parathyroid hormone and chromogranin-A (as measured by a novel sequential hemolytic plaque assay). Endocrinology $1992312638-2642$.

22 Fasciotto BH, Gorr SU, DeFranco DJ, Levine M \& Cohn DV. Pancreastatin, a presumed product of chromogranin A (secretory protein-1) processing inhibits secretion from porcine parathyroid cells in culture. Endocrinology $1989 \mathbf{1 2 5}$ 1617-1622.

23 Drees BM \& Hamilton JW. Pancreastatin and bovine parathyroid cell secretion. Bone and Mineral 199217 335-346.

24 Fujii Y, Moreira JE, Orlando C, Maggi M, Aurbach GD, Brandi ML et al. Endothelin as autocrine factor in the regulation of parathyroid cells. PNAS 199188 4235-4239.

25 Bourdeau A, Sourberbielle JC, Bonnet P, Herviaux P, Sachs CH \& Lieberherr M. Phospholipase $A_{2}$ action and arachidonic acid metabolism in calcium-mediated parathyroid hormone secretion. Endocrinology $19921301339-1344$.

26 Sun F, Ritchie C, Maercklein P \& Fitzpatrick LA. Heterogeneous response to calcium by individual parathyroid cells. Journal of Clinical Investigation 199391 595-601.

27 Conlin PR, Fajtova VT, Mortensen RM, Leboff MS \& Brown EM. Hysteresis in the relationship between serum ionized calcium and intact parathyroid hormone during recovery from induced hyper- and hypocalcemia in normal humans. Journal of Clinical Endocrinology and Metabolism 198969 593-599.

28 Silver J, Russell J, Lettieri D \& Sherwood LM. Regulation by vitamin D metabolites of messenger ribonucleic acid for preproparathyroid hormone in isolated bovine parathyroid cells. PNAS $1985824270-4273$.

29 Russell J, Lettieri D \& Sherwood LM. Suppression by $1,25(\mathrm{OH})_{2} \mathrm{D}_{3}$ of the pre-proparathyroid hormone gene. Endocrinology 1986 $1192864-2866$

30 Naveh-Many T \& Silver J. Regulation of parathyroid hormone gene expression by hypocalcemia, hypercalcemia, and vitamin $\mathrm{D}$ in the rat. Journal of Clinical Investigation $1990 \mathbf{8 6}$ $1313-1319$.

31 Aguilera-Tejero E, Estepa JC, López I, Bas S \& Rodríguez M. Polycystic kidneys as a cause of chronic renal failure and secondary hypoparathyroidism in a horse. Equine Veterinary Journal 200032 167-169.

Received 1 March 2001

Accepted 7 November 2001 